\title{
ОСОБЛИВОСТІ МОТИВАЦІЇ СТУДЕНТІВ-ПЕРШОКУРСНИКІВ В УМОВАХ ДИСТАНЦЙНОГО КАРАНТИННОГО НАВЧАННЯ
}

\author{
Злата Ржевська-Штефан \\ кандидат психологічних наук, доцент, \\ доцент кафедри соціальної роботи, соціальної педагогіки та психології \\ Центральноукраїнський державний педагогічний університет \\ імені Володимира Винниченка \\ 25006, Україна, м. Кропивницький, вул. Шевченка, 1 \\ zlatarzhevska@gmail.com, http://orcid.org/0000-0002-0721-4365
}

\begin{abstract}
Анотація
Статтю присвячено проблемі мотивації до навчання студентів-першокурсників університету в умовах карантинного дистанційного навчання, для яких вимушений і раптовий перехід на дистанційну форму співпав 3 періодом їх адаптації до навчання у виші. Проаналізовано переваги та обмеження дистанційної форми навчання в плані мотивування студентів до досягнення навчальних цілей. Розкрито специфіку мотивації студентів в умовах дистанційного карантинного навчання. 3 метою вивчення особливостей мотивації до навчання студентів першокурсників в умовах карантинного дистанційного навчання використано методику «Шкали академічної мотивації» Т.О. Гордеевої, яка дозволяє визначити рівень розвитку різних мотиваційних конструктів в контексті теорії самодетермінації. Визначено, що у більшості студентів під час академічного року 2020-2021 домінувала внутрішня мотивація, а загальною тенденцією в динаміці мотивації студентів було незначне зниження показників за всіма шкалами як внутрішньої, так і зовнішньої мотивації. Виключенням є показники шкали амотивації, яка несуттєво зросла. Порівняння отриманих результатів із даними про мотивацію першокурсників, що навчались очно, показало, що мотивація студентів, що навчалися в умовах дистанційного та змішаного навчання, виявилась достовірно вищою за всіма шкалами внутрішньої мотивації, а також за шкалами мотивації самоповаги та інтроеційованої мотивації. Виявлені особливості, на наш погляд, визначають специфіку адаптаційних процесів першокурсників в умовах карантинного дистанту. Також отримані результати свідчать, що, попри негативний вплив умов локдауну, студенти виявились достатньо мобілізованими для подолання викликів адаптації до незвичних умов навчання. В свою чергу умови дистанційного навчання спільно 3 викликами пандемії створили підгрунтя для активізації процесів саморегуляції першокурсників і набуття ними суб'єктного досвіду. Водночас цих умов вочевидь недостатньо для того, щоб такі процеси набули масовості та більшої глибини.
\end{abstract}

Ключові слова: внутрішня мотивація, зовнішня мотивація, мотивація саморозвитку, мотивація самоповаги, інтроеційована мотивація, суб’єктність, студенти першокурсники, дистанційне карантинне навчання.

\section{Вступ}

Проблема мотивації учбової діяльності студентів завжди цікавила дослідників. Проте 3 впровадженням карантинного дистанційного навчання ця проблема набула особливої 
актуальності: як викладачі, так і студенти переживають труднощі щодо мотивації освітнього процесу в умовах відсутності прямої взаємодії між іiї учасниками.

Вплив дистанційної форми навчання на мотивацію студентів активно досліджується науковцями останні два десятиліття, оскільки дана форма навчання $є$ однією 3 найсучасніших трендів в системі вищої освіти і має суттєві переваги: масовість, можливість навчатися в будь-якому місці та в будь-який час, доступність для людей із обмеженими можливостями (Смульсон, 2012). Дослідниками підкреслюється потенціал для розвитку в студента навичок самоорганізації, планування та відповідальності за своє навчання (Markova, 2016), які є підгрунтям для розвитку потужної внутрішньої мотивації до навчання.

Але водночас дослідники відзначили, що система дистанційного навчання розрахована переважно на достатньо свідомих студентів, які не потребують постійного контролю з боку викладача (Прибилова, 2017: 32). В умовах такого навчання існує обов'язкова потреба чіткого часового планування, необхідність участі слухачів у коригуванні структури, змісту й ефективності курсу (Іванеко, 2020). Це означає, що успішність студентів за дистанційної форми навчання залежить, передусім, від їхньої мотивації, а також від здатності до самоорганізації, яка притаманна не кожному з них (Красюк, 2010).

Ще одне, не менш суттєве обмеження дистанційної освіти дослідники пов’язують зі зміною характеру соціальної взаємодії між суб'єктами освітнього процесу (Панферов 2020: 284). Слабкою стороною дистанційного навчання є брак живого спілкування між студентом $і$ викладачем (Смульсон, 2012), неможливість взаємодіяти із викладачем в режимі реального часу, отримати від нього вчасний зворотній зв'язок. Мотиваційний потенціал заняття в таких умовах суттєво знижується (Панферов, 2020), студенти відчувають нестачу контролю з боку викладача, а також свою відірваність, ізольованість від процесу навчання.

Дослідники зауважують, що для більшості студентів он-лайн курсів підтримування власної вмотивованості, необхідність брати в свої руки ініціативу і закінчити навчання самостійно, без фізичної присутності однолітків і викладачів, становить проблему (Іванова \& Крилова, 2016). Також є свідчення, що мотивація в умовах дистанційної освіти суттєво відрізняється від мотивації в звичних умовах очного навчання (Панферов, 2020). Зокрема Е. Старк (2019) зазначає, студенти, які навчалися он-лайн, мали значно нижчий рівень як внутрішньої, так і зовнішньої мотивації, порівняно зі студентами очної форми.

Порівняння особливостей мотивації студентів в умовах звичайного дистанційного i карантинного навчання показало, що загалом он-лайн навчання мало негативний вплив на вмотивованість студентів (Meeter, 2020; Меєе, 2021; Biwer, 2021). Студенти відчували зниження мотивації до навчання через брак соціальної взаємодії та невідповідність очікувань змісту і організації навчального процесу (Меєе, 2021), оцінювали своє навчання он-лайн як менш задовільне порівняно з очним, зазначали гіршу присутність на лекціях та групових заняттях, а також відчуття що їх час було змарновано (Meeter, 2020).

В цьому контексті особливий інтерес викликає питання мотивації до навчання студентів першокурсників, для яких вимушений і раптовий перехід на дистанційну форму збігся з періодом їхньої адаптації до навчання у виші. Як відомо, процес і результат адаптації самі по собі виступають мотиваційними чинниками, які скеровують динаміку мотивації в подальші роки. Наразі, ситуація карантинного навчання не могла не вплинути на ці процеси, проте результати даного впливу залишаються поки що не вивченими.

Отже, ми визначили метою нашого дослідження вивчення особливостей мотивації до навчання студентів першокурсників в умовах карантинного дистанційного навчання. Для 
досягнення мети нами були визначені наступні завдання: 1) визначити рівень мотивації до навчання студентів першого курсу університету; 2) здійснити порівняльний аналіз показників мотивації до навчання студентів, що навчалися в умовах карантинного дистанту та в умовах звичного очного навчання; 3) визначити, яким чином навчання в складних умовах вплинуло на адаптаційні процеси першокурсників.

\section{Методи дослідження}

Дослідження було здійснено в контексті теорії самодетермінації Десі та Райана (2012), яка, на наш погляд, є доцільним інструментом для дослідження мотивації в умовах он-лайн навчання. Ця теорія апелює до потреб автономії (відчуття суб'єкта, що він сам визначає своє життя), компетентності (прагнення досягти результату діяльності і відчути власну ефективність) і потреби встановлення зв'язків з іншими людьми, як до найбільш важливих детермінант мотивації. Як відомо, перші два конструкти якнайкраще відповідають таким рисам он-лайн навчання, як гнучкість, збільшення ролі самостійності та саморегуляції, необхідність опанувати технічні навички користування навчальними Інтернет платформами.

В руслі цієї теорії, Т.О. Гордєєва запропонувала методику «Шкали академічної мотивації», яка була нами використана для вивчення мотивації в умовах дистанційного карантинного навчання студентів-першокурсників університету (Гордеева, 2014). Методика побудована на основі питальника AMS P. Валеранда і модифікована для визначення мотивації, як внутрішньої, так і зовнішньої, в контексті теорії самодетермінації. Питальник містить 28 тверджень, щодо яких досліджувані висловлюють міру своєї згоди за 5-бальною шкалою. Твердження групуються за 7 шкалами. 3 них три шкали відносяться до внутрішньої мотивації: пізнавальна мотивація (прагнення дізнатися щось нове, пізнавальний інтерес), мотивація досягнення (прагнення досягти високого результату в навчанні), мотивація саморозвитку (переживання учіння як фактору розвитку самого себе). Наступні три шкали вимірюють зовнішню мотивацію: мотивація самоповаги (прагнення підвищити свою самооцінку та значущість за рахунок навчальної активності), інтроеційована мотивація (спонукою до учіння виступає обов'язок, почуття сорому перед значущими особами) та екстернальна (спонукою виступає вимушеність підкорятися зовнішнім вимогам). Окремою шкалою є шкала амотивації (відсутність інтересу і осмисленості учбової активності).

Також нами були використані відповіді студентів на запитання щодо того, від яких труднощів вони потерпали найбільше під час карантинного дистанційного навчання.

В дослідженні взяли участь студенти перших курсів факультету іноземних мов ЦДПУ імені Володимира Винниченка: 41 студент з набору 2019 року, які навчались переважно очно, і 39 студентів 3 набору 2020 року, які навчалися впродовж першого семестру переважно дистанційно, а другого семестру - на змішаній формі навчання. Дослідження в групі студентів, що навчалися очно, проводилось в кінці першого семестру, до початку карантину. Дослідження в групі студентів, які навчалися на дистанційній та змішаній формі навчання проводилося двічі - в кінці першого і другого семестрів.

\section{Результати та дискусії}

В результаті дослідження академічної мотивації студентів набору 2020 року, які навчалися переважно дистанційно і за змішаною формою навчання, були виявлені такі особливості (див. рис.1). 


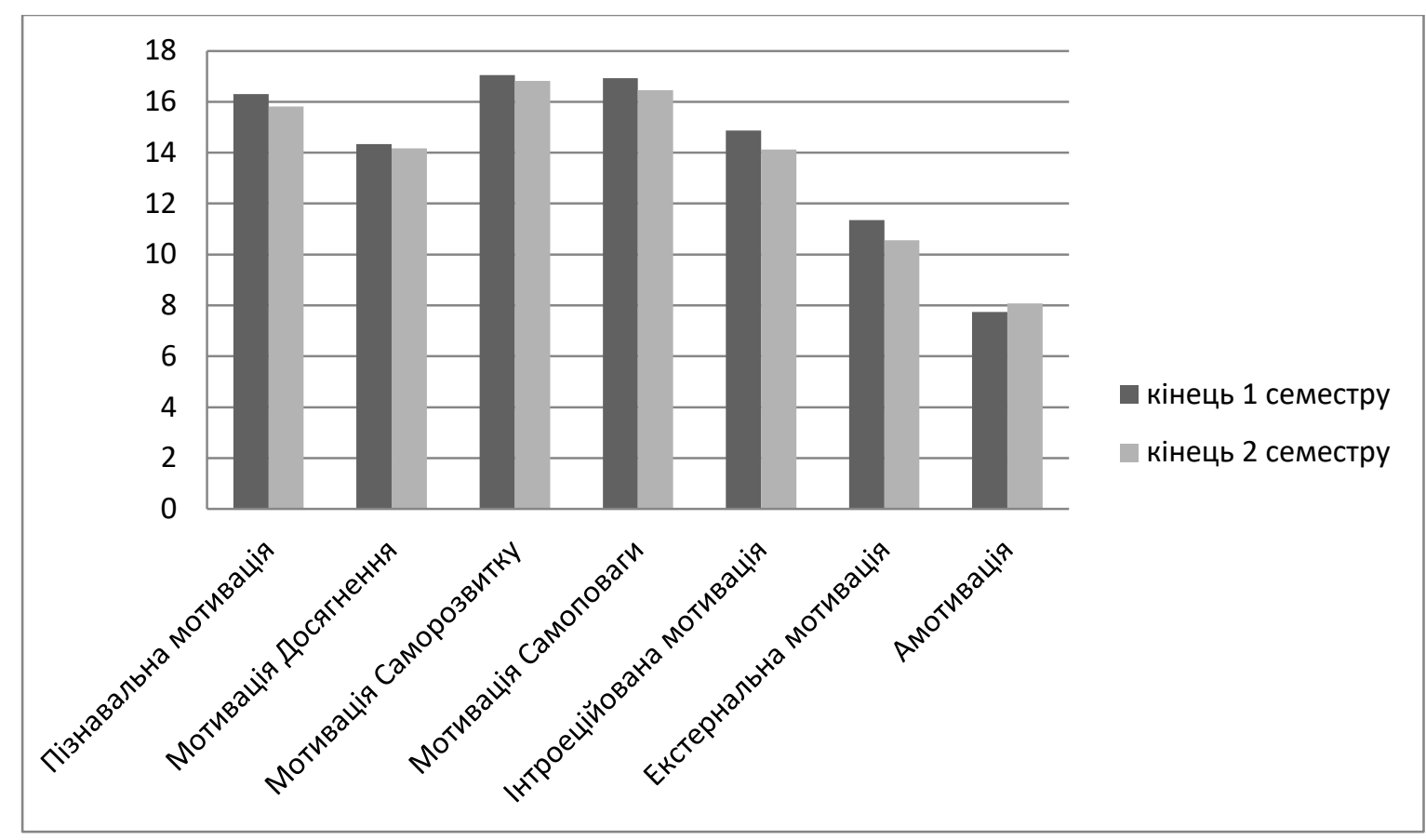

\section{Рис. 1. Динаміка академічної мотивації студентів в умовах дистанційного карантинного навчання}

Під час обох вимірювань найбільші числові показники стосуються мотивації саморозвитку, друге місце посіла мотивація самоповаги, яка $є$ оптимальним для навчання різновидом контрольованої мотивації, а третє - пізнавальна. Четверте місце посіла інтроеційована мотивація, а під час другого зрізу - інтроеційована та мотивація досягнення, яка займала під час першого вимірювання п’яте місце. Екстернальна мотивація та амотивація в обох випадках зайняли відповідно шосте і сьоме місця.

Порівняння середніх значень двох зрізів за критерієм Ст'юдента не виявило жодних суттєвих відмінностей, проте загальною тенденцією стало незначне зниження показників за всіма шкалами як внутрішньої, так і зовнішньої мотивації. Виключенням є показники шкали амотивації, яка несуттєво зросла. Ми схильні інтерпретувати незначне зниження академічної мотивації студентів в контексті глобальних викликів пандемії швидше, як позитивне явище.

Для кращого розуміння змін, що відбулися в мотиваційній сфері студентів внаслідок впливу дистанційного карантинного навчання, порівнювалися середні значення шкал академічної мотивації двох груп першокурсників: 1) набору 2020 (вимірювання в кінці 1 семестру) і 2) набору 2019 (вимірювання в кінці 1 семестру, до початку пандемії). Для порівняння було застосовано критерій Ст'юдента. Отримані результати подано в табл. 1.

Як видно 3 табл. 1., в студентів першокурсників, що навчалися в умовах дистанційного навчання, показники всіх шкал внутрішньої мотивації є достовірно вищими, ніж в групі першокурсників, що навчались очно. Також у них $є$ достовірно вищими показники мотивації самоповаги та інтроеційованої мотивації, натомість інші види мотивації відрізняються несуттєво. Думаємо, що, попри негативний вплив умов локдауну, студенти виявились достатньо мобілізованими для подолання викликів адаптації до незвичних умов навчання і продемонстрували достатньо високий рівень академічної мотивації. 
Таблиия 1.

Показники середніх значень шкал академічної мотивації студентів першого курсу різних академічних років

\begin{tabular}{|c|c|c|c|c|c|c|c|}
\hline \multirow[t]{2}{*}{ Студенти 1-го курсу } & \multicolumn{7}{|c|}{ Мотивація } \\
\hline & 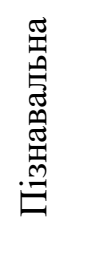 & 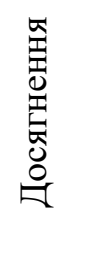 & 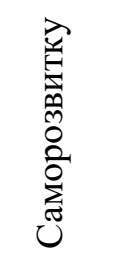 & 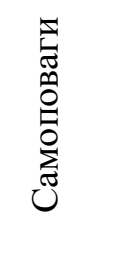 & 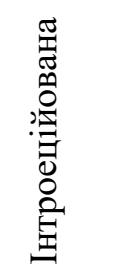 & 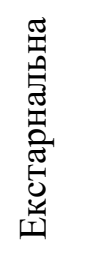 & 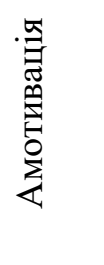 \\
\hline Набір 2019 року $(\mathrm{N}=41)$ & $14,4^{*}$ & $12,7 *$ & $14,9 * *$ & $12,9 * *$ & $11,2 * *$ & 9,8 & 7,5 \\
\hline Набір 2020 року $(\mathrm{N}=39)$ & $16,3^{*}$ & $14,3^{*}$ & $17,5 * *$ & $16,9 * *$ & $14,8^{* * *}$ & 11,6 & 7,7 \\
\hline
\end{tabular}

Примітка: жирним шрифтом в таблиці виділені середні значення, які достовірно відрізняються $(* \mathrm{p}<0,05, * * \mathrm{p}<0,01)$.

Невипадковим вважаємо той факт, що найбільш достовірні відмінності між вибірками стосуються мотивації саморозвитку, самоповаги та інтроеційованої мотивації. Мотивація саморозвитку, що домінує в багатьох внутрішньо мотивованих студентів, має велике значення для першокурсників загалом: вона зумовлена посиленням процесів усвідомлення себе як суб'єктів своєї життєдіяльності під час здійснення життєво важливого вибору вибору майбутньої професії. Саморозвиток - провідна життєва цінність юнацтва, що відіграє суттєву роль у переході до дорослого життя. За даними В.Н. Пуляєвої та А.Н. Неврюєва, при вступі до університету молодими людьми рухає передусім мотивація саморозвитку i пізнання (Пуляєва \& Неврюєв, 2019). За результатами дослідження динаміки спрямованості учбової мотивації студентів різних курсів Т.А. Дворецкої та Л.Р. Ахмадієвої, цей вид мотивації знаходиться на другому місці після мотивації пізнання (Дворецька \& Ахмадієва, 2018). Посилення мотивації саморозвитку в умовах дистанційного карантинного навчання, на наш погляд, є результатом активізації у студентів процесів саморегуляції, пов'язаних із необхідністю приймати на себе відповідальність за регулювання режиму свого навантаження та здійснення самоконтролю в умовах обмеженого зовнішнього стимулювання і контролю. Посилення мотивації самоповаги також вважаємо невипадковим: навчання в умовах пандемії збільшило кількість життєвих викликів, а, відтак, і шляхів досягнення самоповаги юнаками. Думаємо, посилення інтроеційованої мотивації пов'язане із перебуванням студентів під час локдауну вдома, поруч з батьками. В традиційних умовах очного навчання в університеті контроль $з$ боку батьків і викладачів дещо менший, ніж у школі, що, зазвичай, приводить до ііі зниження.

Порівняння виявлених особливостей мотивації першокурсників під час карантинного дистанту з особливостями мотивації першокурсників попередніх років показало, що для них не $є$ типовим домінування пізнавальної мотивації, яка, зазвичай, займає перше місце в мотиваційній сфері першокурсника поруч із мотивацією саморозвитку (Пуляєва \& Неврюєв, 2019). Ми схильні пояснювати цей факт активним залученням в навчальний процес використання мережі Інтернет з ії доступністю будь-якої інформації, з одного боку, а 3 іншого - $з$ тим, що в умовах опосередкованої технічними засобами взаємодії привабливість $\mathrm{i}$ мотиваційний потенціал навчального контенту суттєво знижується (Панферов, 2020).

Порівняння динаміки мотиваційних процесів першокурсників в різних умовах навчання дозволяє зробити висновок про такі суттєві відмінності. Дослідники зазначають, 
що в звичних умовах до кінця першого курсу в студентів, по-перше, спостерігається значне підвищення рівня мотивації досягнення, яке вони пов'язують із розвитком групової динаміки, порівнянням себе із іншими студентами під час практичних і семінарських занять (Дворецкая \& Ахмадієва, 2018: 1927). По-друге, в них значно знижений рівень мотивації самоповаги. Адже студенти, які із зростанням мотивації досягнення починають більше орієнтуватися на зовнішню оцінку результатів своєї навчальної діяльності, втрачають потребу доводити самим собі, що вони здатні успішно вчитися. I, по-третє, внаслідок зниження, порівняно з шкільним навчанням, рівня контролю в університеті з боку викладачів і батьків, у першокурсників суттєво знижується інтроеційована мотивація.

Відсутність такої динаміки мотивації в першокурсників, які навчалися дистанційно під час карантину, передусім пов'язано із особливостями організації процесу навчання, позбавленого тих чинників, які могли б спонукати відповідні зміни: студенти не мали змоги активно взаємодіяти із одногрупниками під час більшості занять, а перебування дома поруч 3 батьками не дало можливості створити умови, які б суттєво відрізнялися від попереднього шкільного навчання. Крім того, в умовах подолання труднощів дистанційного карантинного навчання значення мотивації самоповаги не знизилось: для більшості студентів залишається важливим доводити собі, що вони здатні впоратись з викликами пандемії.

Отже, адаптаційні процеси студентів першокурсників в умовах дистанційного карантинного навчання мають свою специфіку: найбільш важливими мотиваційними конструктами для них є саморозвиток і самоповага.

Згідно досліджень Є.Ю. Савіна (2019), внутрішня мотивація та мотивація самоповаги позитивно корелюють із суб'єктним досвідом - ініціативної і автономної активності, яка призводить до змін в оточуючому світі і самому собі (Савин, 2019). В сфері навчання ці види мотивації виступають ресурсом для акумуляції суб'єктного досвіду, натомість екстернальна мотивація та амотивація блокують його накопичення. 3 огляду на це, можемо припустити, що в першокурсників, які зіштовхнулися з викликами дистанційного карантинного навчання, активно відбувався процес становлення їхньої суб'єктності.

3 метою глибшого дослідження процесів, які відбувалися в мотиваційній сфері першокурсників в напрямку розвитку їхньої суб'єктності, вибірку було поділено на групи, залежно від того, які труднощі виявилися найбільш актуальними в умовах дистанційного навчання впродовж першого семестру. За нашим припущенням, для студентів із низьким рівнем суб’єктності найбільшу складність становить відсутність достатнього зовнішнього контролю і стимулювання (Група А), більш високий рівень суб'єктності відповідає труднощам із необхідністю брати на себе більше відповідальності за те, як навчаєшся (Група Б), а для студентів з високим рівнем суб'єктності труднощі пов'язані не з самоорганізацією, а скоріше із незадоволенням з приводу змісту навчальних курсів (Група В).

Для порівняння було застосовано критерій Ст’юдента. Результати подано в табл. 2.

Як видно з табл. 2, чималою виявилась група студентів, які відчували серйозні труднощі із саморегуляцією і потерпали від недостатнього зовнішнього контролю (Група А), найменш численною - група студентів з високим рівнем саморегуляції (Група В). В групі А рівень мотивації виявився значно нижче. Мотиваційні показники цих двох груп достовірно відрізняються по всіх шкалах внутрішньої мотивації та мотивації самоповаги. Всі показники мотивації групи з середнім рівнем суб'єктності (група Б), нижче, хоча і несуттєво, порівняно з групою з високим рівнем суб'єктності, і вище, ніж в групі з низьким рівнем суб'єктності, проте достовірні відмінності спостерігаються виключно за шкалою «мотивація досягнення». 
Таблиия 2.

\section{Розподіл студентів першого курсу в залежності від характеру актуальних}

\section{труднощів}

\begin{tabular}{|c|c|c|c|c|c|c|c|}
\hline \multirow{2}{*}{$\begin{array}{l}\text { Розподіл студентів 1-го курсу } \\
\text { в кінці першого семестру }\end{array}$} & \multicolumn{7}{|c|}{ Мотивація } \\
\hline & 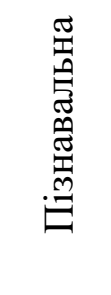 & 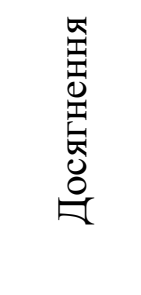 & 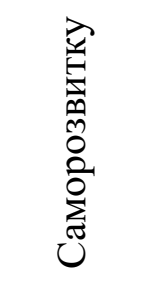 & 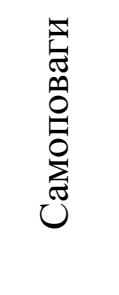 & 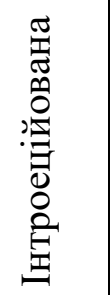 & 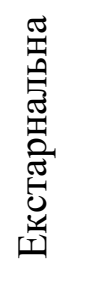 & 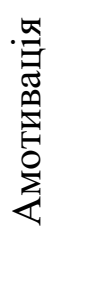 \\
\hline Група А $(48,7 \%)$ & 15,3 & 12,8 & 16,5 & 16,2 & 15,3 & 12,1 & 8,2 \\
\hline Група Б $(32,4 \%)$ & 16,5 & $15,3^{*}$ & 16,7 & 16,6 & 14,2 & 10,8 & 8,2 \\
\hline Група В $(18,9 \%)$ & $18,3^{*}$ & $16,1 * *$ & $19,1 * *$ & $19,1^{*}$ & 15 & 10 & 5,9 \\
\hline
\end{tabular}

Отримані результати не суперечать дослідженню, згідно якого під час пандемії мотивація студентів неоднорідна: студенти, які сприймали он-лайн навчання позитивно і як перевагу, були більш мотивовані; студенти, які сприйняли збільшення своєї автономії швидше, як тягар і перешкоду, виявляли нижчу мотивацію до навчання (Biwer, 2021).

Варто зазначити, що при повторному зрізі в кінці другого семестру мотиваційні показники студентів суттєво не змінилися, проте відбулися зміни в сприйманні ними труднощів: біля половини студентів групи з високим рівнем суб'єктності (Група В) виявили потребу в зовнішньому контролі та стимуляції, або труднощі із необхідністю брати на себе відповідальність за навчання. Водночас певна кількість студентів з групи А виявила більш високий рівень саморегуляції.

Отримані результати засвідчують, що умови дистанційного навчання спільно 3 викликами пандемії створили підгрунтя для активізації процесів саморегуляції першокурсників і набуття ними суб'єктного досвіду. Водночас таких умов вочевидь недостатньо для того, щоб ці процеси набули масовості та більшої глибини. На наш погляд, це неможливо здійснити без спеціальної організації процесу дистанційного навчання, в якому забезпечена психологічна комфортність навчального середовища для користувача, а викладач займається передусім підтримкою (і збереженням) готовності студента до учбової діяльності (Смульсон, 2012).

\section{Висновки}

В результаті проведеного дослідження особливостей академічної мотивації студентівпершокурсників в умовах дистанційного карантинного навчання встановлено, що у більшості студентів під час академічного року 2020-2021 домінувала внутрішня мотивація. Найвищі показники серед шкал має мотивація саморозвитку, на другому місці - мотивація самоповаги, яка є оптимальним для навчання різновидом контрольованої мотивації, на третьому - пізнавальна мотивація. Загальною тенденцією $є$ незначне зниження показників за всіма шкалами, як внутрішньої, так і зовнішньої мотивації. Виключенням є показники шкали амотивації, яка несуттєво зросла. Виявлена динаміка мотивації впродовж карантинного академічного року відрізняється від динаміки мотивації у студентів очного навчання в попередні роки, що, передусім, пов'язано із особливостями організації процесу навчання. 
Порівняно із першокурсниками, які навчались очно, мотивація студентів, що навчалися в умовах дистанційного та змішаного навчання, виявилась достовірно вищою за всіма шкалами внутрішньої мотивації, а також за шкалами мотивації самоповаги та інтроеційованої мотивації. Отже, попри негативний вплив умов локдауну, студенти виявились достатньо мобілізованими для подолання викликів адаптації до незвичних умов навчання і продемонстрували достатньо високий рівень академічної мотивації.

Також виявлено, що адаптаційні процеси студентів першокурсників в умовах дистанційного карантинного навчання мають певні особливості: найбільш важливими мотиваційними конструктами для них є мотивація саморозвитку і самоповаги. Отже, умови дистанційного навчання в купі з викликами пандемії створили підгрунтя для активізації процесів саморегуляції першокурсників і набуття ними суб'єктного досвіду. Водночас таких умов вочевидь недостатньо для того, щоб ці процеси набули масовості та більшої глибини.

Перспективи подальших досліджень вбачаємо у вивченні внутрішньоособистісних чинників, які сприяють підвищенню внутрішньої мотивації студентів в процесі дистанційного навчання, з метою побудови моделі психологічного супроводу адаптації першокурсників в умовах он-лайн навчання.

\section{Лiтература}

1. Гордеева, Т.О., Сычев, О.А., \& Осин, Е.Н. (2014). Опросник «Шкалы академической мотивации». Психологический журнал, 35(4), 96-107.

2. Дворецкая, Т.А., \& Ахмадиева, Л.Р. (2018). Динамика направленности учебной мотивации у студентов разных курсов в течение учебного года. Профессиональное образование в современном мире, 8(2), 1924-1933. https://doi.org/10.15372/PEMW20180222

3. Іванеко, Ю. (2020). Дистанційне навчання як засіб розвитку самоорганізації студентів. Збірник наукових пращь «Проблеми сучасної психологї̈, 49, 60-83. https://doi.org/10.32626/2227-6246.2020-49

4. Красюк, Ю.М. (2010). Проблеми мотивачї навчальної діяльності студентів дистаниійної форми навчання. Режим доступу: https://ir.kneu.edu.ua/bitstream/handle/ 2010/25885/ZE_Krasiuk.pdf?sequence=1\&isAllowed=y

5. Панферов, В.Н., Безгодова, С.А., Васильева, С.В., Иванов, А.С., \& Микляева, А.В. (2020). Эффективность обучения и академическая мотивация студентов в условиях онлайнвзаимодействия с преподавателем (на примере видеолекции). Социальная психология $u$ общество, 11(1), 127-143. https://doi.org/10.17759/sps.2020110108

6. Прибилова, В. (2017). Проблеми та переваги дистанційного навчання у вищих навчальних закладах України. Проблеми сучасної освіти, 4, 27-36. Режим доступа: https://periodicals.karazin.ua/issuesedu/article/view/8791

7. Пуляєва, В.Н., \& Неврюев, А.Н. (2019). Академическая мотивация: как фактор удовлетворенности образовательными услугами. Креативная экономика, 3, 533-544. Режим доступа: http://elib.fa.ru/art2019/bv480.pdf

8. Савин, Е.Ю. (2019). Соотношение субъектного опыта студента с внешней и внутренней мотивацией академической активности. Мир науки. Педагогика и психология, 2. Режим доступа: https://cyberleninka.ru/article/n/sootnoshenie-subektnogo-opyta-studenta-s-vneshneyi-vnutrenney-motivatsiey-akademicheskoy-aktivnosti

9. Смульсон, Ю.Л. (2012). Дистанційне навчання: психологічні засади. (Монографія). Кіровоград : Імекс-ЛТД.

10. Biwer, F., Wiradhany, W., oude Egbrink, M., Hospers, H., Wasenitz, S., Jansen, W., \& de Bruin, A. (2021). Changes and Adaptations: How University Students Self-Regulate Their Online Learning During the COVID-19 Pandemic. Front. Psychol., 12, 642593. https://doi.org/10.3389/fpsyg.2021.642593

11. Deci, E., \& Ryan, R.M. (2012). Motivation, Personality, and Development within Embedded Social Contexts: An Overview of Self-Determination Theory. In The Oxford Handbook of Human Motivation, 1-26. http://dx.doi.org/10.1093/oxfordhb/9780195399820.013.0006 
12. Markova, T., Glazkova, I., \& Zaborova, E. (2017). Quality Issues of Online Distance Learning. Procedia - Social and Behavioral Sciences, 237, 685-691. https://doi.org/10.1016/j.sbspro.2017.02.043

13. Meeter, M., Bele, T., Hartogh, C. d., Bakker, T., de Vries, R.E., \& Plak, S. (2020). College students' motivation and study results after COVID-19 stay-at-home orders. https://doi.org/10.31234/osf.io/kn6v9

14. Meşe, E., \& Sevilen, Ç. (2021). Factors influencing EFL students' motivation in online learning: A qualitative case study. Journal of Educational Technology \& Online Learning, 4(1), 11-22. Retrieved from https://dergipark.org.tr/en/pub/jetol/issue/60134/817680

15. Stark, E. (2019). Examining the Role of Motivation and Learning Strategies in the Success of Online vs. Face-to-Face Students. Online Learning, 23(3), 234-251. http://dx.doi.org/10.24059/olj.v23i3.1556

\section{References}

1. Gordeeva, T.O., Sychev, O.A., \& Osin, E.N. (2014). Oprosnik "Shkalyi akademicheskoy motivatsii" ["Academic motivation scales" questionnaire]. Psihologicheskiy zhurnal Psychological journal, 35(4), 96-107 [in Russian].

2. Dvoretskaia, T.A., \& Akhmadieva, L.R. (2018). Dinamika napravlennosti uchebnoy motivatsii $\mathrm{u}$ studentov raznyih kursov $\mathrm{v}$ techenie uchebnogo goda [Orientation dynamic of students' educational motivation of different courses during the academic year]. Professionalnoe obrazovanie $v$ sovremennom mire - Professional education in the modern world, 8(2), 19241933. https://doi.org/10.15372/PEMW20180222 [in Russian].

3. Ivaneko, Yu. (2020). Dystantsiine navchannia yak zasib rozvytku samoorhanizatsii studentiv [Distance learning as a means of developing students' self-organization]. Zbirnyk naukovykh prats "Problemy suchasnoi psykholohii" - Collection of scientific works "Problems of modern psychology”, 49, 60-83. https://doi.org/10.32626/2227-6246.2020-49 [in Ukrainian].

4. Krasiuk, Yu.M. (2010). Problemy motyvatsii navchalnoi diialnosti studentiv dystantsiinoi formy navchannia [Problems of students' learning motivation in distance education].

Retrieved from https://ir.kneu.edu.ua/bitstream/handle/2010/25885/ZE_Krasiuk.pdf?sequence= 1 \&isAllowed=y [in Ukrainian].

5. Panferov, V.N., Bezgodova, S.A., Vasileva, S.V., Ivanov, A.S., \& Miklyaeva, A.V. (2020). Effektivnost obucheniya i akademicheskaya motivatsiya studentov v usloviyah onlaynvzaimodeystviya $\mathrm{s}$ prepodavatelem (na primere videolektsii) [Efficiency of learning and academic motivation of students in conditions of online interaction with the teacher (on the example of video-lecture)]. Sotsialnaya psihologiya $i$ obschestvo - Social Psychology and Society, 11(1), 127-143. https://doi.org/10.17759/sps.2020110108 [in Russian].

6. Prybylova, V. (2017). Problemy ta perevahy dystantsiinoho navchannia u vyshchykh navchalnykh zakladakh Ukrainy [Problems and advantages of revote education in higher educational institutions of Ukraine]. Problemy suchasnoi osvity - Problems of modern education, 4, 27-36. Retrieved from https://periodicals.karazin.ua/issuesedu/article/ view/8791 [in Ukrainian].

7. Pulyaeva, V.N. \& Nevryuev, A.N. (2019). Akademicheskaya motivatsiya: kak faktor udovletvorennosti obrazovatelnyimi uslugami [Academic motivation as a factor of satisfaction with educational]. Kreativnaya ekonomika - Creative Economy, 3, 533-544. Retrieved from https://periodicals.karazin.ua/issuesedu/article/view/8791 [in Russian].

8. Savin, E.Yu. (2019). Sootnoshenie subyektnogo opyita studenta s vneshney i vnutrenney motivatsiey akademicheskoy aktivnosti [Correlation of student's subject experience with extrinsic and intrinsic motivation of academic activity]. Mir nauki. Pedagogika i psihologiyaThe world of science. Pedagogy and Psychology, 2. Retrieved from https://mirnauki.com/PDF/70PSMN219.pdf [in Russian].

9. Smulson, Yu.L. (2012). Dystantsiine navchannia: psykholohichni zasady [Remote education: psychological issues]. Kirovohrad : Imeks-LTD [in Ukrainian].

10. Biwer, F., Wiradhany, W., oude Egbrink, M., Hospers, H., Wasenitz, S., Jansen, W., \& de Bruin, A. (2021). Changes and Adaptations: How University Students Self-Regulate Their Online Learning During the COVID-19 Pandemic. Front. Psychol., 12, 642593. https://doi.org/10.3389/fpsyg.2021.642593 
11. Deci, E., \& Ryan, R.M. (2012). Motivation, Personality, and Development within Embedded Social Contexts: An Overview of Self-Determination Theory. In The Oxford Handbook of Human Motivation, 1-26. http://dx.doi.org/10.1093/oxfordhb/9780195399820.013.0006

12. Markova, T., Glazkova, I., \& Zaborova, E. (2017). Quality Issues of Online Distance Learning. Procedia - Social and Behavioral Sciences, 237, 685-691. https://doi.org/10.1016/j.sbspro.2017.02.043

13. Meeter, M., Bele, T., Hartogh, C. d., Bakker, T., de Vries, R.E., \& Plak, S. (2020). College students' motivation and study results after COVID-19 stay-at-home orders. https://doi.org/10.31234/osf.io/kn6v9

14. Meşe, E., \& Sevilen, Ç. (2021). Factors influencing EFL students' motivation in online learning: A qualitative case study. Journal of Educational Technology \& Online Learning, 4(1), 11-22. Retrieved from https://dergipark.org.tr/en/pub/jetol/issue/60134/817680

15. Stark, E. (2019). Examining the Role of Motivation and Learning Strategies in the Success of Online vs. Face-to-Face Students. Online Learning, 23(3), 234-251. http://dx.doi.org/10.24059/olj.v23i3.1556

\title{
THE FIRST YEAR STUDENTS' MOTIVATION FEATURES IN EMERGENT REMOTE EDUCATION SETTINGS Zlata Rzhevska-Shtefan \\ PhD in Psychology, Associate Professor, Associate Professor of the Department of Social Work, Social Pedagogy and Psychology
}

Central Ukrainian State Pedagogical University named after Volodymyr Vynnychenko

1, Shevchenko Str., Kropyvnytskyi, 25006

zlatarzhevska@gmail.com, http://orcid.org/0000-0002-0721-4365

\begin{abstract}
The article deals with the problem of the first-year university students' motivation to study under conditions of emergent remote education during the COVID-19 pandemic, for whom a forced and sudden transition to distance learning coincided with the period of their adaptation to higher education. Advantages and limitations of the distance form of learning are analyzed in the context to motivate students to achieve educational goals. Specific features of students' motivation under conditions of emergent remote education are disclosed. In order to research into features of the firstyear students' motivation to learn under those conditions, the Academic Motivation Scales "Academic motivation scales" questionnaire by T.O. Gordeeva was used. The technique permits to define development levels of various motivational constructs in the context of the selfdetermination theory. It has been identified that in academic years of 2020-2021, for the majority of students there dominated intrinsic motivation, whereas the general motivation dynamics tendency was a minor decline of indicators of all the scales for both intrinsic and extrinsic types of motivation. The only exception to the rule has become the amotivation scale indicators, demonstrating a slight growth. Comparison of the results obtained with the data regarding the firstyear students involved in face-to-face learning shows that motivation of the students who studied in online and mixed type environments appears to be veraciously higher by all scales of intrinsic motivation as well as by the scales of self-respect and introjected motivation. The features disclosed, in our understanding, define the specific features of the first-year students' adaptation processes within the emergency remote education. Besides, the results testify to the fact that, in spite of a negative lockdown influence, the students tend to be mobilized enough to face the challenges posed by the need to adapt to the learning conditions. Therefore, online settings coupled with the pandemic challenges, have created the stimulus to expedite the self-regulation processes of the first-year students. At the same time, those conditions are obviously not enough for the processes to gain mass and depth.

Keywords: intrinsic motivation, extrinsic motivation, personal growth motivation, motivation for self-respect, subjectivity, first-year students, emergency remote education.
\end{abstract}

